\title{
Editorial: A Farthing Candle
}

'The conversation then took a philosophical turn', says Boswell, writing of a private supper at the Turk's Head coffee house on 28 July 1763 . It often did when Johnson was one of the company, and this must be one of the reasons why a reader in Australia wrote last year to ask if we were planning a special issue of Philosophy in 1984 to mark the 200th anniversary of Johnson's death. This farthing candle is all that we have felt able to offer. It honours one whose robustness of judgment and force of expression teach lessons that philosophers have commonly needed to learn. His place in philosophy is something like that of Lewis Carroll: besides making a number of remarks on the subject himself, he has also provided the epigraph or motto for many an essay or chapter by a more prolific contributor to the field. It is true that he wrote The History of Rasselas, Prince of Abyssinia, and that it is one of the few works in English that can claim with any fitness to be what Boswell called it: 'an admirable philosophical Romance'. Otherwise he is remembered by philosophers for a small number of observations of which readers of this journal, to use some words of Johnson himself, will need rather to be reminded than informed. $\mathrm{He}$ undertook to refute Berkeley's idealism by kicking a large stone. He declared that we know that the will is free and there's an end on't. Otherwise the best known remark about philosophy to be found in his conversation was made by Oliver Edwards: 'You are a philosopher, Dr Johnson. I have tried too in my time to be a philosopher; but, I don't know how, cheerfulness was always breaking in.'

There are others, especially on topics in morals and religion and letters, that deserve to be better known. 'Talking on the subject of taste in the arts, he said, that difference of taste was, in truth, difference of skill'. When Goldsmith was quoted as saying: 'As I take my shoes from the shoemaker, my coat from the taylor, so I take my religion from the priest', Johnson would have none of this Socratic analogizing: 'Sir, he knows nothing; he has made up his mind about nothing'. Socrates was again implicitly rebuked when there was a discussion of Rousseau's treatise on the inequality of mankind:

It gave rise to an observation by $\mathrm{Mr}$ Dempster, that the advantages of fortune and rank were nothing to a wise man, who ought to value only merit. JOHNSON: 'If man were a savage, living in the woods by himself, this might be true; but in civilized society we all depend upon each other, and our happiness is very much owing to the good opinion of mankind. Now, Sir, in civilized society, external advantages make us more respected. A man with a good coat upon his back meets with a 


\section{Editorial}

better reception than he who has a bad one. Sir, you may analyse this, and say what is there in it? But that will avail you nothing, for it is a part of a general system. Pound St Paul's church into atoms, and consider any single atom; it is, to be sure, good for nothing: but, put all these atoms together, and you have St Paul's church. So it is with human felicity, which is made up of many ingredients, each of which may be shewn to be very insignificant. In civilized society, personal merit will not serve you so much as money will. Sir, you may make the experiment. Go into the street, and give one man a lecture on morality, and another a shilling, and see which will respect you most.'

His conversation shows again and again his grasp of a truth that the work of philosophers sometimes causes their readers to question: that there are rights and wrongs, truths and falsehoods, even where there is deep disagreement about matters of tangled complexity: 'Always remember this, that after a system is well settled upon positive evidence, a few partial objections ought not to shake it. The human mind is so limited, that it cannot take in all the parts of a subject, so that there may be objections raised against any thing. There are objections against a plenum, and objections against a vacuum; yet one of them must certainly be true.' Yet, as this remark itself suggests, he was aware of the limitations of our mental powers when measured against the tasks that are set before them. What he said of Mr Thomas Sheridan and his scholarly efforts might be applied more widely: 'Sir, it is burning a farthing candle at Dover, to shew light at Calais.' 